4. Karanfil LV, Murphy M, Josephson A, et al. A cluster of vancomycin-resistant Enterococcus faecium in an intensive care unit. Infect Control Hosp Epidemiol 1992;13:195-200.

5. Green M, Barbadora K, Michaels M. Recovery of vancomycinresistant gram-positive cocci from pediatric liver transplant recipients. J Clin Microbiol 1991;29:2503-2506.

6. Livoernese LL, Jr, Dias S, Samel C, et al. Hospital-acquired infection with vancomycin-resistant Enterococcus faecium transmitted by electronic thermometers. Ann Intern Med 1992;117:112-116.

7. Boyce JM, Opal SM, Chow JW, et al. Outbreak of multidrugresistant Enterococcus faecium with transferable van B class vancomycin resistance. J Clin Microbiol 1994;32:1148-1153.

8. Olsen RJ, Lynch P, Coyle MB, Cummings J, Bokete T, Stamm WE. Examination gloves as barriers to hand contamination in clinical practice. JAMA 1993;270:350-353.

9. Johnson S, Gerding DN, Olson MM, et al. Prospective, controlled study of vinyl glove use to interrupt Clostridium difficle nosocomial transmission. Am J Med 1990;88:137-140.

10. Hospital Infection Control Practices Advisory Committee (HICPAC). Recommendations for preventing the spread of vancomycin resistance. Infect Control Hosp Epidemiol 1995;16:105113.

11. Wells VD, Wong ES, Murray BE, Coudron PE, Williams DS, Markowitz SM. Infections due to beta-lactamase-producing, high-level gentamicin-resistant Enterococcus faecalis. Ann Intern Med 1992;116:285-292.

12. Wade JJ, Desai N, Casewell MW. Hygienic hand disinfection for the removal of epidemic vancomycin-resistant Enterococcus faecium and gentamicin-resistant Enterobacter cloacae. J Hosp Infect 1991;18:211-218.

13. Arroyo JC, Harrison K, Birgenheier R. The stethoscope-a vector of infection? [letter] Infect Control 1983;4:189.

14. Casewell MW, Desai N. Survival of multiply-resistant Klebsiella aerogenes and other gram-negative bacteria on finger-tips. $J$ Hosp Infect 1983;4:350-360.

15. Musa EK, Desai N, Casewell MW. The survival of Acinetobacter calcocaceticus inoculated on fingertips and on formica. J Hosp Infect 1990;15:219-227.

16. Buxton AE, Anderson RL, Werdegar D, Atlas E. Nosocomial respiratory tract infection and colonization with Acinetobacter calcoaceticus. Epidemiologic characteristics. Am J Med 1978;65:507-513.

17. Fujita K, Lilly HA, Ayliffe GAJ. Spread of resistant gram-negative bacilli in burns unit. J Hosp Infect 1982;3:29-37.

18. Getchell-White SI, Donowitz LG, Gröschel DHM. The inanimate environment of an intensive care unit as a potential source of nosocomial bacteria: evidence for long survival of Acinetobacter calcoaceticus. Infect Control Hosp Epidemiol 1989;10:402-407.

19. Steere A, Mallison GF. Hand-washing practices for the prevention of nosocomial infections. Ann Intern Med 1975;83:683-690.

\title{
Congress's Office of Technology Assessment Closed
}

\section{by Gina Pugliese, RN, MS Medical News Editor}

In September 1995, the 23-yearold US Office of Technology Assessment (OTA) closed its doors, following months of debate. Critics of the decision say the $\$ 22$ million budget was an easy target for the government. Earlier this year, the House had voted to reduce the OTA budget to $\$ 15$ million and link it with the Congressional Research Service. However, the Senate voted to close it rather than using funds from other agencies to keep it going.
Proponents of the closure said that OTA's expert analysis can be replicated by other advisory agencies, but OTA defenders argue that the agency has a unique decision-making process that is bipartisan and brings a real-world view to a problem. One of the agency's strongest defenders, Congressman Amo Houghton (Republican New York), said, "most Congressman are illiterate, and as we go into the next century, they need a sense of where science is taking this country."

OTA was created in 1972 after Congress became discouraged with the bias of reports it was getting on technologic and scientific develop- ments. Regarding OTA closure, OTA Director Dr. Roger Herdman, a physician at OTA since 1983, says "When congressmen look for advice and bring in the executive branch or the private sector, they will get the advice with the agendas and biases of those institutions." Herdman says that the agency still had reports in the pipeline that it planned to issue before it closed, including reports on antibiotics, healthcare information technology, technology and HIV vaccines, and laser surgery.

FROM: Firshein J. Death warrant for US technology assessment agency. Lancet 1995;346:430. 